\author{
J. Klimentova, P. Vojtisek \\ Charles University, Prague, Czech Republic \\ (E-mail:pavojt@natur.cuni)
}

\title{
Variation of the stereoparameters for description geometry of calix[4]arenes - more suitable solution for «flat systems»
}

\begin{abstract}
This article deals with a variation of previously introduced parameters $\alpha, \beta$, and $\delta$ which were used to describing the all possible conformations of these compounds, cone, partial cone, 1,2- and 1,3-alternate conformers of methylene- and heteroatom-bridged calix[4]arenes. Usefulness of these parameters $\alpha, \beta, \delta$ have been already demonstrated, but, it seems, to be more suitable to do any variations them for flat systems. The background for the parameters $\alpha, \beta, \delta$ lies in the representation of the scale of the angles of the calix[4]arene rings towards the reference plane. The original scale $0^{\circ}-360^{\circ}$ for these angles depicts very well the differences between the calix[4] arene conformations but has two significant disadvantages. The first one is the discontinuity of the scale. The angles $\alpha_{i}$ range approximately from $0^{\circ}$ to $110^{\circ}$ and from $250^{\circ}$ to $360^{\circ}$ because of the sterical hindrance that would occur should the calixarene phenyl ring enter the cavity. The second disadvantage is the discontinuity at the point $\alpha_{i}=0^{\circ}$, it means the case of flat systems. These flat systems are usually the "transitions states' between the calixarene conformations and cannot be observed using parameters $\alpha, \beta$, $\delta$. To eliminate the difficulties in describing the 'transition states' between the calix[4]arene conformations caused by the discontinuities of the original scale, the new scale should be introduced. New parameters $\alpha^{\prime}, \beta^{\prime}$, $\delta^{\prime}$ were introduced by subtracting $360^{\circ}$ for each 'negative' ring present in the structure (one for partial cone conformers, two for 1,2- and 1,3-alternate conformers); after the parameters $\alpha, \beta, \delta$ are calculated.
\end{abstract}

Keywords: supramolecular chemistry, stereochemistry of calix[4]arene, conformation, transition states, torsion angles, distorsion parameters, analysis of structural data from CCDC, cluster analysis.

\section{Variation of the parameters $\alpha, \beta, \delta$}

The background for the parameters $\alpha, \beta, \delta$ lies in the representation of the scale of the angles of the calix[4] arene rings towards the reference plane [1-3]. The original scale $0^{\circ}-360^{\circ}$ (see Fig. 3 in [2]) for these angles depicts very well the differences between the calix[4]arene conformations (separation into the distinct 'clusters') $[3,4]$ but has two significant disadvantages. The first one is the discontinuity of the scale. The angles $\alpha_{i}$ range approximately from $0^{\circ}$ to $110^{\circ}$ and from $250^{\circ}$ to $360^{\circ}$ because of the sterical hindrance that would occur should the calixarene phenyl ring enter the cavity $[3,4]$.

The second disadvantage is the discontinuity at the point $\alpha_{i}=0^{\circ}$, it means the case of flat systems. This discontinuity is principally responsible for the distinct separation into the 'clusters' observed in [3,4] on Fig. 4-7, but as a result the 'transitions states' between the calixarene conformations cannot be observed. And mainly these 'transitions states' are flat systems.

To eliminate the difficulties in describing the 'transition states' between the calix[4]arene conformations caused by the discontinuities of the original scale, the new scale, depicted in the second part of Figure 1, should be introduced. This scale differs from the first one in the values of the 'negative' phenyl ring angles; these angles are calculated from those in the first scale by subtracting $360^{\circ}$. However, the negative values of some phenyl ring angles might cause difficulties in parameter $\alpha, \beta, \delta$ calculation. Therefore we decided for transformation of the existing parameters $\alpha, \beta, \delta$ by subtracting $360^{\circ}$ for each 'negative' ring present in the structure (one for partial cone conformers, two for 1,2- and 1,3-alternate conformers); after the parameters $\alpha, \beta, \delta$ are calculated. The formulae for the resulting parameters $\alpha^{\prime}, \beta^{\prime}, \delta^{\prime}$ are given in the next paragraph.
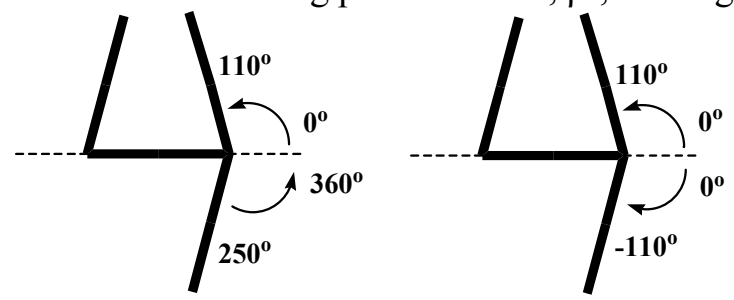

Figure 1. The dual representation of the scale of phenyl ring angles $\boldsymbol{\alpha}_{\mathrm{i}}$ 
A new set of parameters, $\alpha^{\prime}, \beta^{\prime}, \delta^{\prime}$ was therefore introduced to describe the 'transition states' between the calix[4]arene conformations. These parameters are defined using the original $\alpha, \beta, \delta$ parameters for four conformers of calix[4]arenes as follows:

cone calix[4]arenes: $\alpha^{\prime}=\alpha ; \beta^{\prime}=\beta ; \delta^{\prime}=\delta$;

partial cone calix[4]arenes: $\alpha^{\prime}=\alpha-90^{\circ} ; \beta^{\prime}=\beta-360^{\circ} ; \delta^{\prime}=\delta-360^{\circ}$;

1,2-alternate calix[4]arenes: $\alpha^{\prime}=\alpha-180^{\circ} ; \beta^{\prime}=\beta ; \delta^{\prime}=\delta-720^{\circ}$;

1,3-alternate calix[4]arenes: $\alpha^{\prime}=\alpha-180^{\circ} ; \beta^{\prime}=\beta-720^{\circ} ; \delta^{\prime}=\delta$.

Aplication of the new parameters $\alpha^{\prime}, \beta^{\prime}, \delta^{\prime}$

The $\alpha^{\prime}-\beta^{\prime}$ and $\alpha^{\prime}-\delta^{\prime}$ plots for the group of calix[4]arenes with methylene bridges are depicted on Figures 2 and 3.

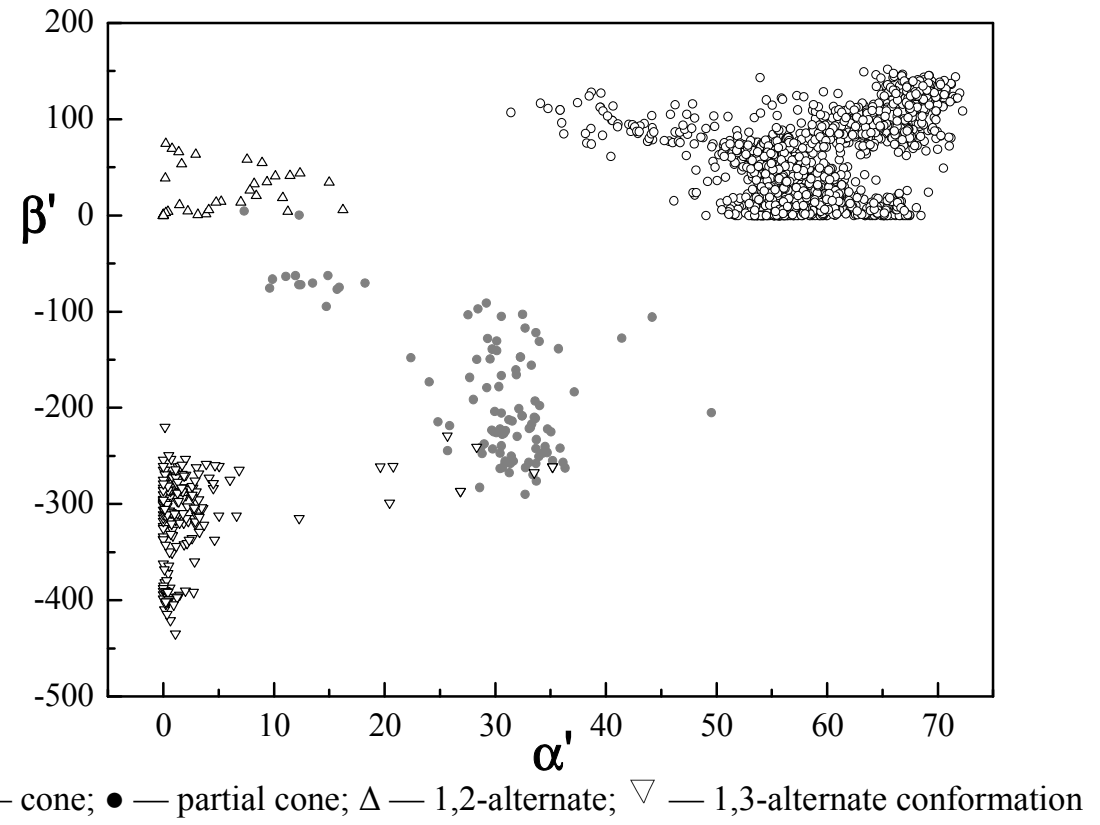

Figure 2. The $\alpha^{\prime}-\beta$ 'plot for the group of calix[4]arenes with methylene bridge groups

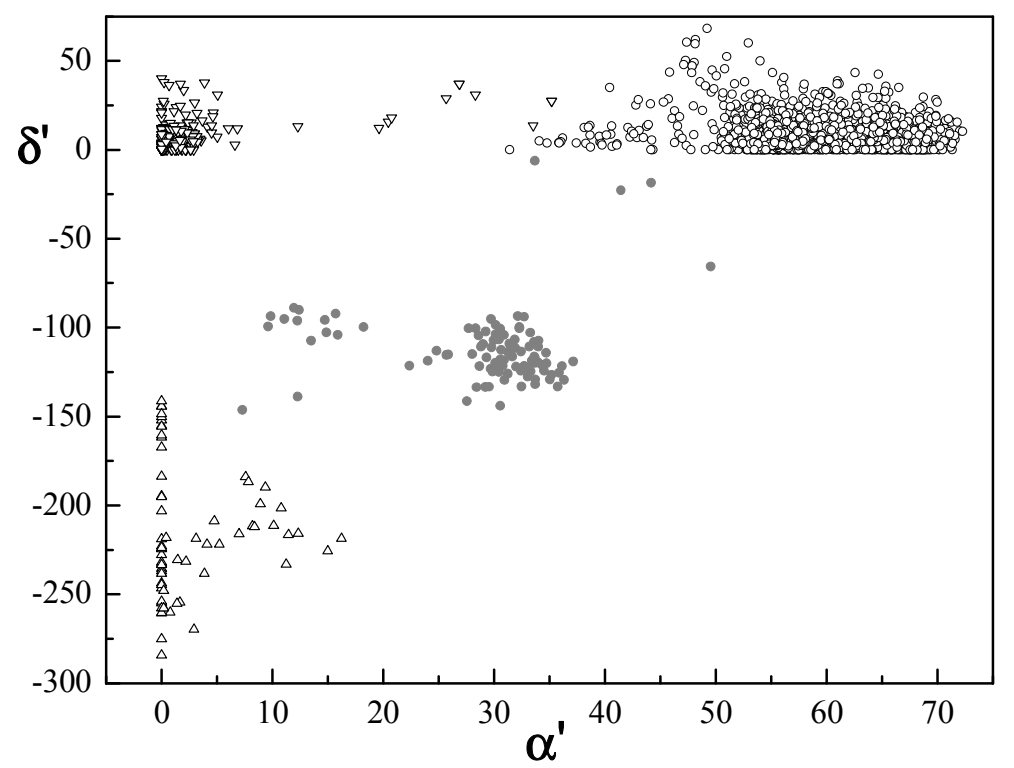

$\circ-$ cone; $\bullet-$ partial cone; $\Delta-1,2$-alternate; $\nabla-1,3$-alternate conformation

Figure 3. The $\alpha^{\prime}-\delta^{\prime}$ plot for the group of calix[4]arenes with methylene bridge groups 
From the $\alpha^{\prime}-\beta^{\prime}$ plot, it is obvious that two hits from the partial cone group lie within the 1,2-alternate group. The plot is more transparent and better than using parameters $\alpha-\beta$. These structures are ZALGOI (Fig. 4) and a very open structure KOCQIC (Fig. 5). The similarity of these structures to the 1,2-alternate group is readily observable. The distinct group separated from the partial cone conformers ('on the path' to the 1,2-alternate conformers) is the group of single atom 'triple-bridged' structures which possess very opened cavities (see structure ABIHIC, Fig. 4). These structures have been already discussed.

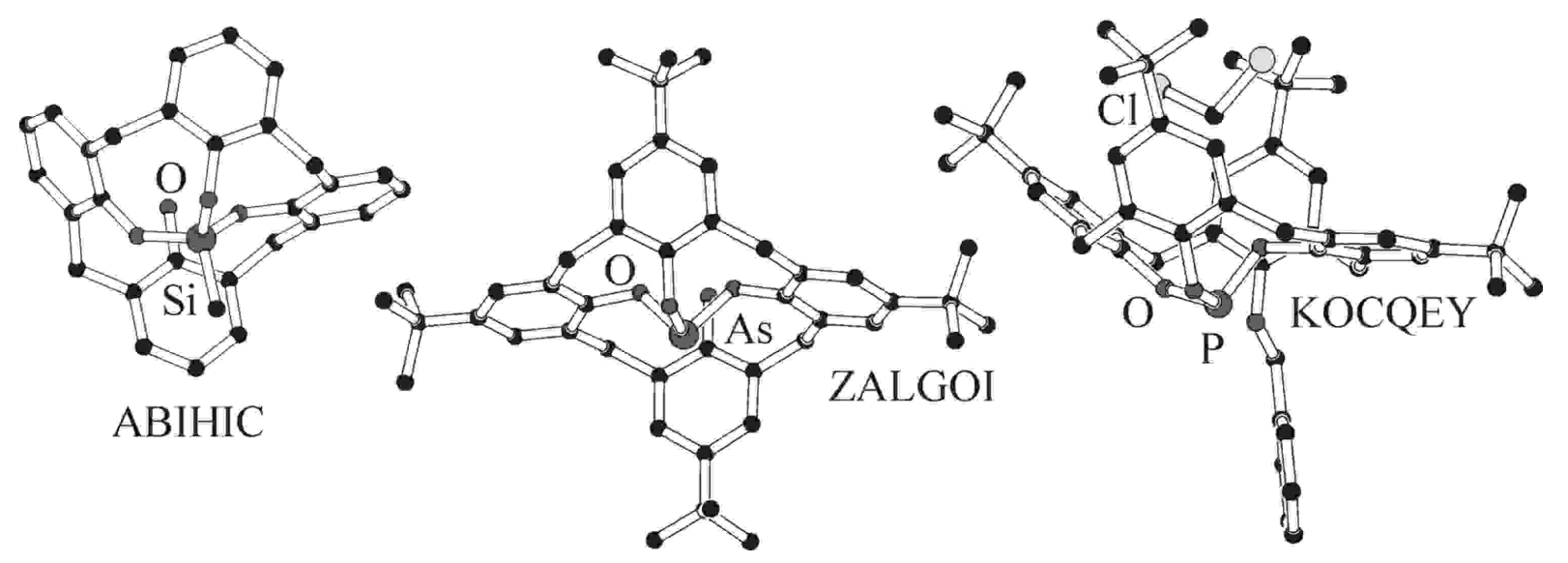

Figure 4. Structures ABIHIC, ZALGOI and KOCQEY [5]

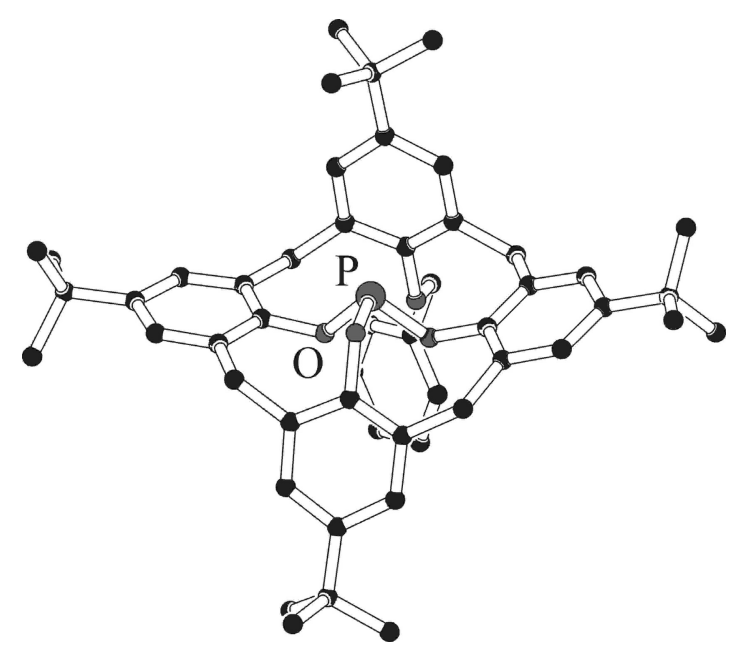

Figure 5. Structure KOCQIC [5]

From the $\alpha^{\prime}-\beta^{\prime}$ plot it can be clearly seen that four hits from the partial cone group are close to the cone group. The structures GUBTAY (no Fig.) and KOCQEY [4] (Fig. 4) belong to this group.

From the two plots it is obvious that several hits from the 1,3-alternate group are very close to both cone and partial cone group (hits with $\alpha^{\prime}>10^{\circ}$ ). The unifying feature of these structures is the presence of calix[4]arene skeleton strongly deformed towards $\mathrm{C}_{2 \mathrm{v}}$ geometry; close to that of saddle shaped calix[4]resorcinarenes. The main reason behind this deformation is missing of two opposite phenolic oxygen atoms at the lower rim and the resulting $\pi, \pi$-stacking between the other opposite calix[4]arene phenyl rings (e.g. structure GUCYUY, Fig. 6). The $\pi, \pi$-stacking might occur even between calix[4]arene phenyl rings from different molecules. Representative example of this group of structures is the structure GUCYUY (the deformation in this case is due to the presence of $\pi, \pi$-stacking between the opposite calix[4]arene phenyl rings and between one calix[4]arene phenyl ring and the phenyl ring from the crown ether bridge). 


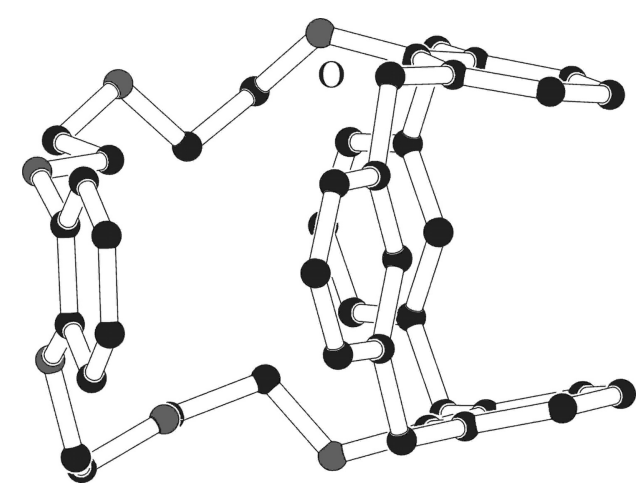

Figure 6. Structure GUCYUY [5]

The $\alpha^{\prime}-\beta^{\prime}$ and $\alpha^{\prime}-\delta^{\prime}$ plots for the group of calix[4]arenes with heteroatom bridges are depicted on Figures 7 and 8 . From both plots, it is obvious that several structures from the partial cone group (structures with $\alpha^{\prime} \sim 10-20^{\circ}$ ) are close to the 1,2-alternate group. These structures possess relatively opened cavities; structure SEBZEE [5] is a clathrate with a trimeric structure, the other two structures possess open cavities due to the presence of $\pi, \pi$-stacking between one calix[4]arene phenyl ring and an aromatic moiety from complex ligand molecule (see structure YAQKAD, Fig. 9 and VAVRAM, Fig. II-5 in [4]).

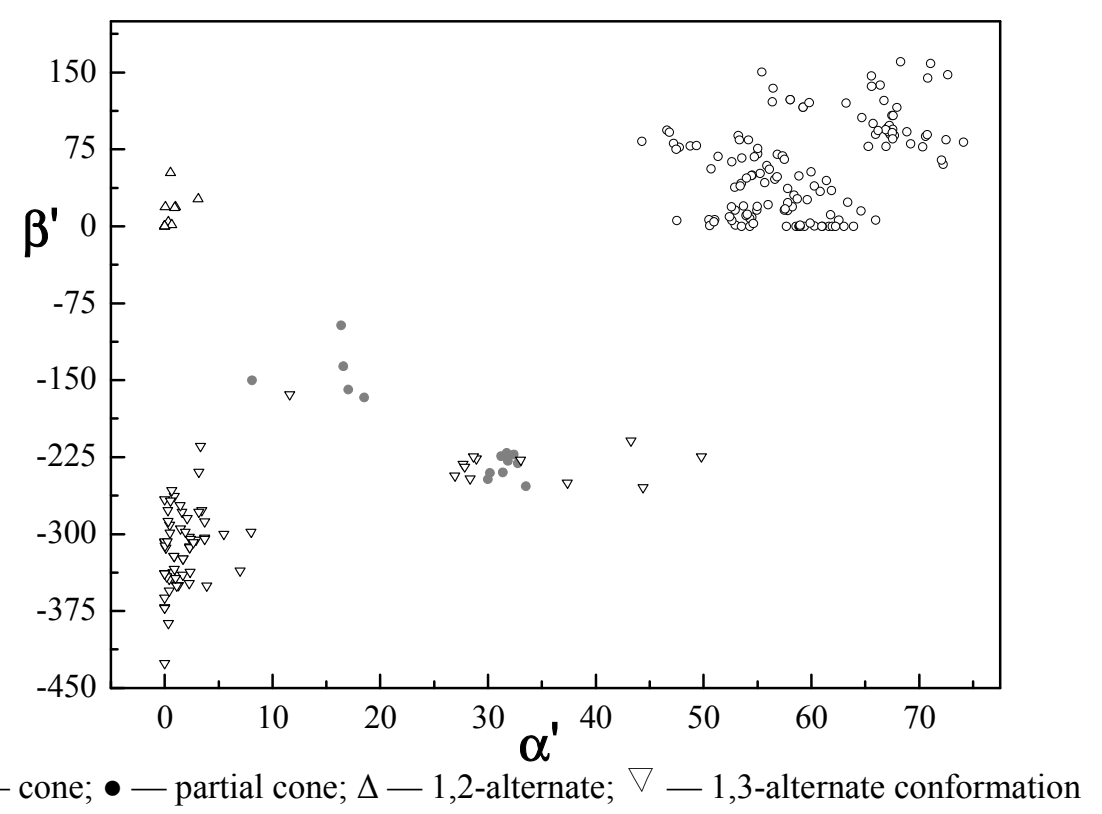

Figure 7. The $\alpha^{\prime}-\beta^{\prime}$ plot for the group of calix[4] arenes with heteroatom bridges

From the $\alpha^{\prime}-\beta^{\prime}$ plot it can be observed that several cone structures are 'on the path' to the 1,3-alternate group (structures with $\alpha^{\prime} \sim 45^{\circ}$ ). These structures (e.g. structure ACAJAQ see Fig. 10) all exist in a very flat pinched cone conformation (a remarkable deformation towards $\mathrm{C}_{2 \mathrm{v}}$ symmetry) because of a distal cis- coordination of a metal ion to the four phenolic oxygen atoms. Structure TETQEO [5] also belongs to this group. In this case proximal cis- coordination of two potassium ions causes a marked opening of the calixarene cavity (symmetry approximately $\mathrm{C}_{4 \mathrm{v}}$ ) and therefore lower value of the parameter $\alpha^{\prime}$. Examples of the distal cis- coordination are given on the structure ACAJAQ (Fig. 10) and BEPKOX (see [3]). 


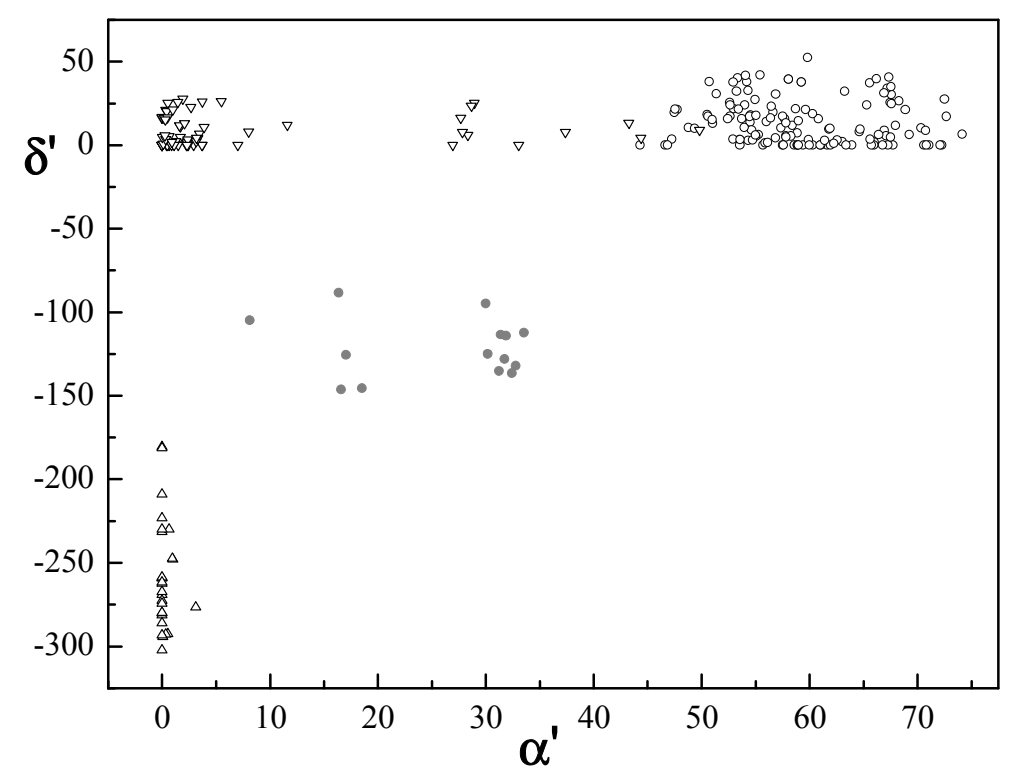

$\circ-$ cone; $\bullet$ - partial cone; $\Delta-1,2$-alternate; $\nabla-1,3$-alternate conformation

Figure 8 . The $\alpha^{\prime}-\delta^{\prime}$ plot for the group of calix[4]arenes with heteroatom bridges

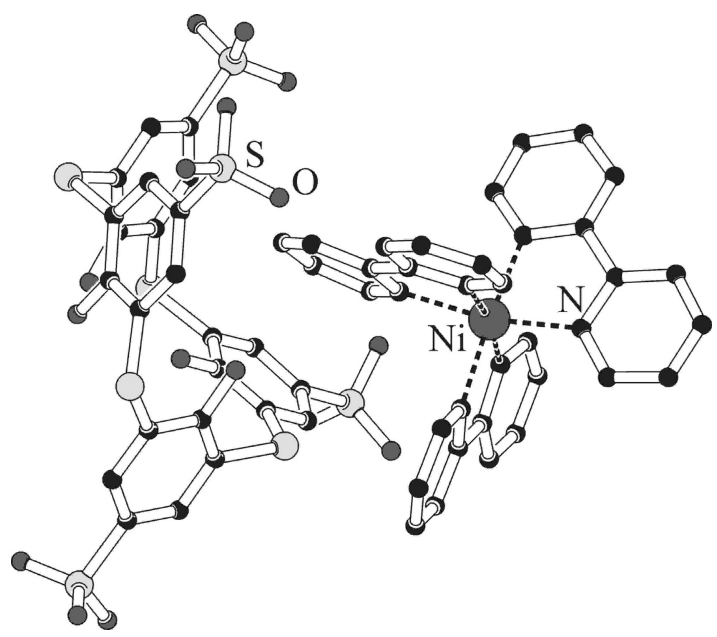

Figure 9. Structure YAQKAD [5]

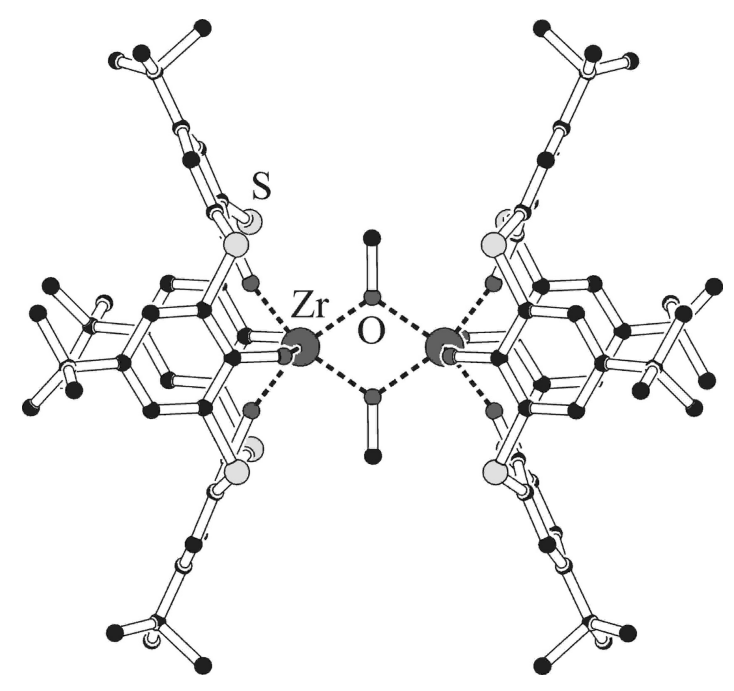

Figure 10. Structure ACAJAQ [5] 
It is obvious from the two plots, that several hits from the 1,3-alternate group are very close to both cone and partial cone group (hits with $\alpha^{\prime}>20^{\circ}$ ). The unifying feature of these structures is the presence of calix[4]arene skeleton strongly deformed towards $\mathrm{C}_{2 \mathrm{v}}$ geometry; close to that of saddle shaped calix[4]resorcinarenes. All these structures (e.g. FEZZIU, HAXGAP, NODJOF, SAXJEG [5]) lack at least two distal phenolic oxygen atoms at the lower rim and with the only exception of SAXJEG (Fig. II-25 in [4]) have distally $m$ - substituted two phenyl rings. The geometry of these structures is governed by the presence of $\pi, \pi$-stacking between the two other opposite calix[4]arene phenyl rings; sometimes even between calix[4]arene phenyl rings from different molecules (structures FEZZIU, HAXGAP [5]). The representative examples of this group are the structures FEZZIU (Fig. II-23 in [4] and HAXGAP (Fig. 11).

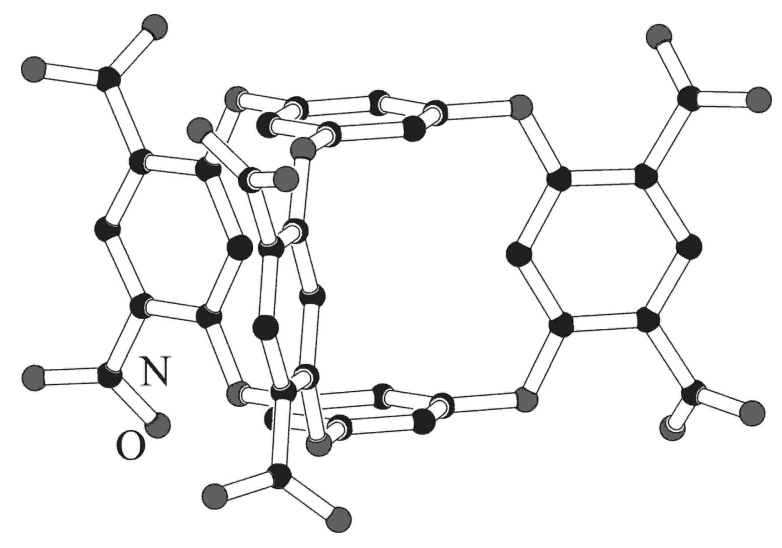

Figure 11. Structure HAXGAP [5]

The only hit from this group with $\alpha^{\prime} \sim 10^{\circ}$ close to the 'renegade' group of partial cone structures (structure TAZMEN, see the $\alpha^{\prime}-\beta^{\prime}$ plot) has a very open structure probably due to $m$-substitution of two opposite calix[4]arene rings (Fig. 12).

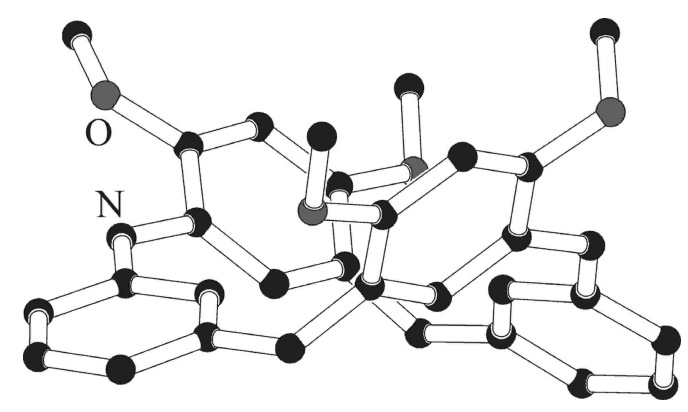

Figure 12. Structure TAZMEN [5]

Conclusion

The utility of parameters $\alpha, \beta, \delta$ in describing the conformation of calix[4]arenes and the impact of inter/intramolecular interactions present in the structure on the symmetry of the cone calix[4]arene base frame has been evaluated in review [3, 4]. These parameters can describe deformations of the scaffold symmetry. A deformation towards $C_{2 v}$ (flattened cone structures) is reflected by the parameter $\beta$; a deformation towards $\mathrm{C}_{\mathrm{s}}$ symmetry is best reflected by the parameter $\delta$. The parameter areflects the degree of 'opening' of the calix[4]arene cavity.

The «original» parameters $\alpha, \beta, \delta$ are based on the angles at the scale from $0^{\circ}$ to $360^{\circ}$ for $\alpha_{\mathrm{i}}$, having two significant disadvantages. The first one is the discontinuity of the scale (see Fig. 1). The angles $\alpha_{\mathrm{i}}$ range approximately from $0^{\circ}$ to $110^{\circ}$ and from $250^{\circ}$ to $360^{\circ}$ because of the sterical hindrance that would occur should the calixarene phenyl ring enter the cavity. The second disadvantage is the discontinuity at the point $\alpha_{i}=0^{\circ}$, it means the case of flat systems. But these flat systems are usually the 'transitions states' ${ }^{6}$ between the calixarene conformations and cannot be acceptable described using the parameters $\alpha, \beta, \delta$.

To eliminate the difficulties in describing the 'transition states' between the calix[4] arene conformations caused by the discontinuities of the original scale, the new scale for $\alpha_{i}$ (see Fig. 1) should be introduced. New 
parameters $\alpha^{\prime}, \beta^{\prime}, \delta^{\prime}$ were introduced easily by subtracting $360^{\circ}$ for each 'negative' ring present in the structure (one for partial cone conformers, two for 1,2- and 1,3-alternate conformers); after the parameters $\alpha, \beta$, Sarecalculated.

These new parameters are not quite different approach, their properties and connections with a symmetry of calixarenescafold are remained. They are able to reflect same effect as the original parameters $\alpha, \beta$, $\delta$. It is only small «correction», but it seems to be useful for description and modelling flat systems and for studying transitions between calixarene conformations.

\title{
Acknowledgements
}

We thank RNDr. Ivana Císařová, CSc. for the provision of CSD data. Access to the Cambridge Crystallographic Data Centre was sponsored by the Grant Agency of the Czech Republic (grant No. 203/99/0067). We thank Dr. Ye. Minayeva for her help with Russian part of text. We thank Professor S. Kenzhetayeva for her help with Kazakh part of text.

\section{References}

1 Klimentová, J., \& Vojtíšek, P. (2005). Stereochemistry of calix[4]arenes. Materials Structrure, 12, 151-152.

2 Klimentová, J., \& Vojtíšek, P. (2007). New receptors for anions in water: Synthesis, characterization, X-ray structures of new derivatives of 5,11,17,23-tetraamino-25,26,27,28-tetrapropyloxycalix[4]arene. Journal of Molecular Structure, 826(1), 48-63 and references therein.

3 Klimentová, J., Mádlová, M., Němečková, P., Palatinusová, L., Vojtíšek, P., \& Lukeš, I. (2017). Conformations of calix[4]arenes - an investigation based on CSD data. Part I. Cone conformers of methylene- and heteroatom-bridged calix[4]arenes. Bulletin of the Karaganda University. Ser. Chemistry, 85(1), 21-46.

4 Klimentová, J., Mádlová, M., Němečková, P., Palatinusová, L., Vojtíšek, P., \& Lukeš, I. (2017). Conformations of calix[4]arenes - an investigation based on CSD data. Part II. Partial cone, 1,2-alternate and 1,3-alternate conformers of methyleneand heteroatom-bridged calix[4]arenes. Bulletin of the Karaganda University. Ser. Chemistry, 88(4), 8-38.

5 CSD Version 2.3.6 (update August 2006), Cambridge Crystallographic Data Centre (CCDC).

\section{Я. Климентова, П. Войтишек}

\section{Каликс[4]арендердің геометриясын сипаттау үшін стереопараметрлерін өзгерту — «жазық жүйелер» үшін қолайлы шешім}

\begin{abstract}
Мақалада каликс[4]арендер барлық мүмкін болатын конформацияларын, нақтылап айтқанда, жартылай конустың, метиленді және гетероатомды көпіршелері бар 1,2- және 1,3-альтернантты конфермелерін, сипаттау үшін қолданылған, алдында енгізілген $\alpha, \beta$ және $\delta$ параметрлерін өзгерту қарастырылды. Осы $\alpha, \beta, \delta$ параметрлерінің жарамдылығы көрсетілген, бірақ оларды жазық жүйелер үшін қолданған дұрыстау болады. $\alpha, \beta, \delta$ параметрлері үшін алғышарт каликс[4]арендердің сақина бұрыштарына салыстыру жазықтығына қатысты шкала ұсыну болып тұр. Осы бұрыштар үшін бастапқы масштаб $0^{\circ}-360^{\circ}$ каликс[4]арендердің конформациялары арасындағы өзгешеліктерді жақсы көрсетеді, бірақ екі елеулі кемшілік бар. Біріншісі - ол шкаланың үзілуі. Кеңістіктік кедергілер салдарынан, бұрыштар $\alpha_{i} 0^{\circ}$ дан $110^{\circ}$ және $250^{\circ}$ ден $360^{\circ}$ шектеуінде жатыр. Егер куысқа каликсарендік фенил сақинасы енсе, осы іске асады. Екінші кемшілік $-\alpha_{i}=0^{\circ}$ нүктесіндегі үзілу, бұл жазық жүйелерінің жағдайлары. Осы жазық жүйелер, әдетте, каликсарендер конформациялары арасындағы «ауысу күйлері» болып табылады және $\alpha, \beta, \delta$ параметрлерін қолданғанда байқалмайды. Бастапқы шкаланың үзілуі нәтижесінде пайда болатын, каликс[4]арендер конформациялары арасындағы «ауыспалы күйлерді» сипаттауда байқалатын осындай қиындықтарды жою үшін жаңа масштаб енгізу қажет. Жаңа параметрлер $\alpha^{\prime}, \beta^{\prime}, \delta^{\prime}$ құрылымдағы әрбір «теріс» сақина үшін $360^{\circ}$ алып тастау арқылы енгізілген (біреуі конустың жартылай конформерлері үшін, екеуі 1,2- және 1,3альтернантты конформер үшін); соңынан $\alpha, \beta, \delta$ параметрлері есептелген.
\end{abstract}

Кілт сөздер: супрамолекулалық химия, каликс[4]арендердің стереохимиясы, конформациялар, ауыспалы күйлер, торсионды бұрыштар, ауытқу параметрлері, CCDC құрылымдық мәліметтерінің талдауы, кластерлік талдау. 
Я. Климентова, П. Войтишек

\title{
Изменение стереопараметров для описания геометрии каликс[4]аренов - более подходящее решение для «плоских систем»
}

\begin{abstract}
В статье рассмотрено изменение ранее введенных параметров $\alpha, \beta$ и $\delta$, которые были использованы для описания всех возможных конформаций, а именно: конуса, частичного конуса, 1,2- и 1,3альтернантных конформеров каликс[4]аренов с метиленовыми и гетероатомными мостиками. Пригодность параметров $\alpha, \beta, \delta$ была продемонстрирована, но, по-видимому, более целесообразно использовать их для плоских систем. Предпосылка для параметров $\alpha, \beta, \delta$ лежит в представлении шкалы углов колец каликс[4]аренов по отношению к плоскости сравнения. Исходный масштаб $0^{\circ}-360^{\circ}$ для этих углов очень хорошо показывает различия между конформациями каликс[4]аренов, но имеет два существенных недостатка. Первый - это разрыв шкалы. Углы $\alpha_{i}$ лежат в пределах от $0^{\circ}$ до $110^{\circ}$ и от $250^{\circ}$ до $360^{\circ}$ из-за стерических препятствий, которые произойдут, если в полость войдет каликсареновое фенильное кольцо. Второй недостаток - разрыв в точке $\alpha_{i}=0^{\circ}$, это означает случай плоских систем. Эти плоские системы обычно являются «состояниями переходов» между конформациями каликсарена и не могут наблюдаться с использованием параметров $\alpha, \beta, \delta$. Чтобы устранить трудности при описании «переходных состояний» между конформациями каликс[4]арена, вызванными разрывами исходной шкалы, следует ввести новый масштаб. Новые параметры $\alpha^{\prime}, \beta^{\prime}, \delta^{\prime}$ были введены путем вычитания $360^{\circ}$ для каждого «отрицательного» кольца, присутствующего в структуре (один - для частичных конформеров конуса, два — для 1,2- и 1,3-альтернантных конформеров), далее были рассчитаны параметры $\alpha, \beta, \delta$.
\end{abstract}

Ключевые слова: супрамолекулярная химия, стереохимия каликс[4]аренов, конформации, переходные состояния, торсионные углы, параметры отклонения, анализ структурных данных CCDC, кластерный анализ. 